\title{
Review of the geographical distribution of the white-spotted frog Chiasmocleis albopunctata (Boettger, 1885) (Anura, Microhylidae)
}

\author{
Maurício da Cruz Forlani ${ }^{1,5}$, Paula Hanna Valdujo', Dante Pavan ${ }^{2}$, \\ Adriano Oliveira Maciel ${ }^{3}$ \& Pedro Luiz Vieira Peloso P $^{3,4}$ \\ ${ }^{1}$ Museu de Zoologia, Universidade de São Paulo - USP, \\ Av. Nazaré, 481, Ipiranga, CEP 04263-000, São Paulo, SP, Brazil \\ ${ }^{2}$ Instituto de Biociências, Universidade de São Paulo - USP, Rua do Matão, Travessa 14, \\ Cidade Universitária, CEP 05508-900, São Paulo, SP, Brazil \\ ${ }^{3}$ Laboratório de Herpetologia, Museu Paraense Emílio Goeldi/CZO, Av. Perimetral, 1901, Terra Firme, \\ CEP 66077-530, Belém, PA, Brazil \\ ${ }^{4}$ Division of Vertebrate Zoology (Herpetology) and Richard Gilder Graduate School, \\ American Museum of Natural History, Central Park West at 79 ${ }^{\text {th }}$ Street, 10024, New York, NY, USA \\ ${ }^{5}$ Corresponding author: Maurício da Cruz Forlani, e-mail: mcforlani@ gmail.com
}

FORLANI, M.C., VALDUJO, P.H., PAVAN, D., MACIEL, A.O. \& PELOSO, P.L.V. Review of the geographical distribution of the white-spotted frog Chiasmocleis albopunctata (Boettger, 1885) (Anura, Microhylidae). Biota Neotrop. 11(3): http://www.biotaneotropica.org.br/v11n3/en/abstract?article+bn02411032011

Abstract: This paper presents a review of the geographical distribution of Chiasmocleis albopunctata (Boettger, 1885), based on data from literature, scientific collections, and field notes. Our reviewing significantly enlarges the distribution of the species within the Brazilian territory, with new records for the states of Bahia, Maranhão, and Tocantins. Among all species of the genus, $C$. albopunctata can be considered the one with the widest latitudinal and altitudinal ranges, as well as greater environmental plasticity.

Keywords: chiasmocleis, microhylidae, gastrophryninae, distribution map.

FORLANI, M.C., VALDUJO, P.H., PAVAN, D., MACIEL, A.O. \& PELOSO, P.L.V. Revisão da distribuição do sapo-de-pintas-brancas Chiasmocleis albopunctata (Boettger, 1885) (Anura, Microhylidae). Biota Neotrop. 11(3): http://www.biotaneotropica.org.br/v11n3/pt/abstract?article+bn02411032011

Resumo: Este trabalho apresenta uma revisão da distribuição geográfica de Chiasmocleis albopunctata (Boettger, 1885), a partir de dados da literatura, coleções científicas e anotações em campo. Os dados aqui apresentados ampliam consideravelmente a distribuição da espécie dentro do território brasileiro, com novos registros para os estados da Bahia, Maranhão, Tocantins. Dentre todas as espécies do gênero, C. albopunctata pode ser considerada a espécie que apresenta maior variação altitudinal e latitudinal, bem como maior plasticidade ambiental.

Palavras-chave: chiasmocleis, microhylidae, gastrophryninae, mapa de distribuição. 


\section{Introduction}

Chiasmocleis Méhely 1904 is the most diverse genus of Microhylidae in the Neotropical region (Frost 2011). The genus comprises 25 described species and ranges from Panama to northern Argentina. For most species data on geographic distribution is considerably limited, and some of them are known only from their type localities (Frost 2011). One exception is Chiasmocleis albopunctata, the type species of the genus, for which several published records are available, and has a wide distribution through open habitats in South America (Caramaschi \& Cruz 1997, De La Riva et al. 2000, Gordo \& Campos 2003, Brasileiro et al. 2005, Uetanabaro et al. 2007, Frost 2011, Schulze et al. 2009). The species ranges from eastern Bolivia, Paraguay to southern and central Brazil (Aquino et al. 2004, Silva et al. 2009). Chiasmocleis albopunctata is a small frog with the dorsum usually grayish with white blotches, especially on snout and dorsolateral region; ventral region usually brownish with many white spots (Figure 1); toes and fingers slightly fringed, lack webbing and terminal disks (Caramaschi \& Cruz 1997). The advertisement call of Chiasmocleis albopunctata was described from two populations, from Bolivia (De La Riva et al. 1996) and Brazil (Oliveira-Filho \& Giaretta 2006). The structure of the calls from the two populations differs in presence of harmonic bars and number of pulses, suggesting the possibility of existence of two different species or strong geographic variation in call. Unfortunately the populations from type locality, Paraguay, does not have their calls described, preventing any taxonomic conclusions based on call structure. Although Silva et al. (2009) published a geographical distribution map of Chiasmocleis albopunctata we intend here to update this map for a more comprehensive view of the distribution of this frog. We do this by adding new records resulted from several years of fieldwork, examining occurrence records in herpetological collections (mainly from Brazil), and also reviewing the relevant literature.

\section{Material and Methods}

We examined specimens of Chiasmocleis albopunctata in the following collections: Coleção Herpetológica da Univeridade de Brasília (CHUNB); Coleção de Anfíbios, Departamento de
Zoologia, Universidade Estadual Paulista, campus Rio Claro $(\mathrm{CFBH})$; Smithsonian Institution, National Museum of Natural History (USNM); Museu Nacional do Rio de Janeiro (MNRJ); Museu Paraense Emílio Goeldi, (MPEG); Museu de Zoologia João MoojenUniversidade Federal de Viçosa (MZUFV); Museu de Zoologia, Universidade de São Paulo (MZUSP); Universidade Federal de Goiás (ZUFG); Universidade Federal do Mato Grosso (UFMT); Coleção Científica da UNESP de São José do Rio Preto (DZSJRP). We confirmed the identification of all specimens examined, following the diagnoses present on the literature as: presence of a white or whitish bar on the snout, canthus rostralis, and upper eyelid; ventral region with large whitish blotches on a gray background; reduced number of spines and fingers and toes slightly fringed (Caramaschi \& Cruz 1997). Previous records available on literature were also included (Caramaschi \& Cruz 1997, De La Riva et al. 1996, 2000, Gordo \& Campos 2003, Brasileiro et al. 2005, Oliveira-Filho \& Giaretta 2006, Uetanabaro et al. 2007, Giaretta et al. 2008, Schulze et al. 2009, Silva et al. 2009). For literature records we were unable to check the identification of most specimens.

In addition, all authors collected the specimens of Chiasmocleis albopunctata during fieldworks in several localities during the last decade, whose natural history notes are also presented here. All specimens collected were deposited in one of the collections mentioned above.

\section{Results and Discussion}

We found several unpublished records of Chiasmocleis albopunctata, but a review of all available specimens is beyond our objectives. Therefore, for localities with many specimens collected we only present one or few voucher specimens (Appendix I). The distribution map (Figure 2) was based on 94 records for which we had confidence in the available geographic coordinates.

The record for the state of Pará is questionable and may not be a reliable record. Two specimens were found in the MZUSP collection, which were mixed up in a jar with several Ctenophryne geayi specimens. Originally the specimens were housed at the Werner C. A. Bokermann collection (WCAB), now incorporated into the MZUSP herpetological collection. Unfortunately the label provides
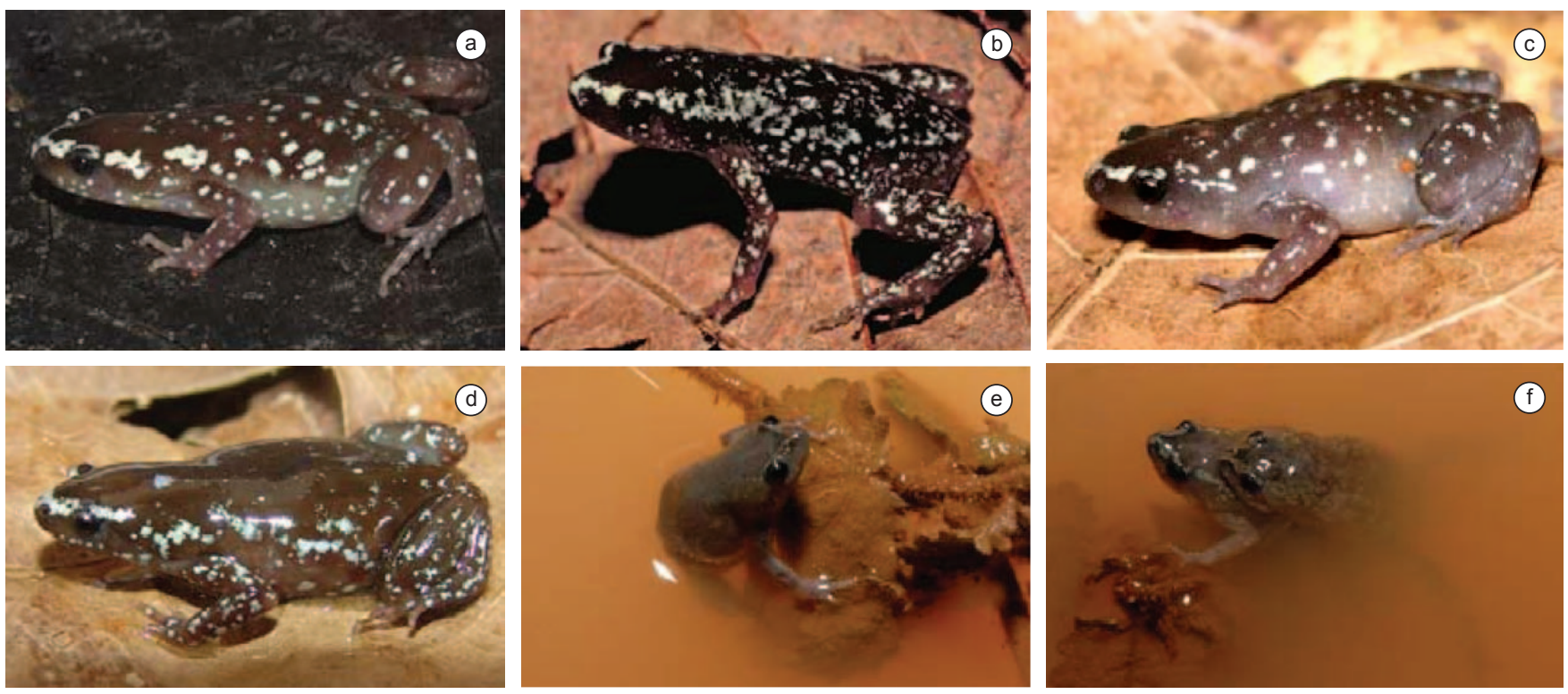

Figure 1. Chiasmocleis albopunctata, in life. Specimens from a) Araguatins, state of Tocantins, Brazil (MPEG 29414); b) Departamanto Santa Cruz, Bolivia, Photo by J. Köhler; c) Departamento Santa Cruz, Bolivia, Photo by Martin Jansen; d) Buri, state of São Paulo, Brazil. e) A calling male, and f) an amplectant pair in a temporary pond, Água Boa, state of Mato Grosso, Brazil. 
only the locality and State of collection "Tucuruí, Pará", the collector and date are not provided. Although the predominant vegetation in this region is Amazon forest, the substitution of original vegetation (forest) to pasture or natural open areas, can be the determining factors for the occurrence of Chiasmocleis albopunctata on the region. Although Silva et al. (2009) indicate that C. albopunctata seems to be associated to the presence of forest (in the state of São Paulo), our data (see below) and the relevant literature (McDiarmid \& Foster 1987, De La Riva et al. 2000, Aquino et al. 2004, Brasileiro et al. 2005, Pavan 2007) do not show any restrict association to forest areas. However, the species is indeed likely to occur in Pará, since specimens were found very close to the state border in the north state of Tocantins (MPEG 29414).

Our data show that Chiasmocleis albopunctata present wide latidutinal and longitudinal ranges and also a great altitudinal variability: it has been collected at latitudes ranging from $6^{\circ} 00^{\prime} \mathrm{S}$ in Araguatins, Tocantins to $25^{\circ} 18^{\prime} \mathrm{S}$ in Assuncion, Paraguay. The species occur in elevations ranging from 59 m a.s.l. in Asunción, Paraguay to $1200 \mathrm{~m}$ a.s.l. in Alto Paraíso, state of Goiás, Brazil.
All others species of the genus do not show such wide range. The species that occur in Atlantic Forest are those with more restrict range (Cruz et al. 1997, Forlani 2010). In the Amazon forest, Chiasmocleis avilapiresae, C. bassleri and C. ventrimaculata are those who have greater range, although smaller than C. albopunctata (Peloso \& Sturaro 2008, Forlani 2010).

In addition to its wide distribution, $C$. albopunctata seems to be a generalist species regarding its habitat use. It has been recorded in many different types of habitat such as interfluvial grasslands (Parque Nacional da Chapada das Mesas, Maranhão), gallery forests (Parque Nacional das Emas and Três Ranchos, Goiás, and Reserva Ecológica do Roncador, Brasília, Distrito Federal) and transition areas of Cerrado and Atlantic Forest in Mesophytic Semideciduous Forest in the state of São Paulo, Brazil (Silva et al. 2009).

Males were found calling at night after heavy rains, associated to temporary ponds close to unpaved roads (Alto Araguaia, Água Boa and Barra do Garças, state of Mato Grosso) and in flooded gallery forests (Água Boa, Mato Grosso). Amplectant pairs were usually found inside of temporary ponds (Figure 1f). Chiasmocleis albopunctata

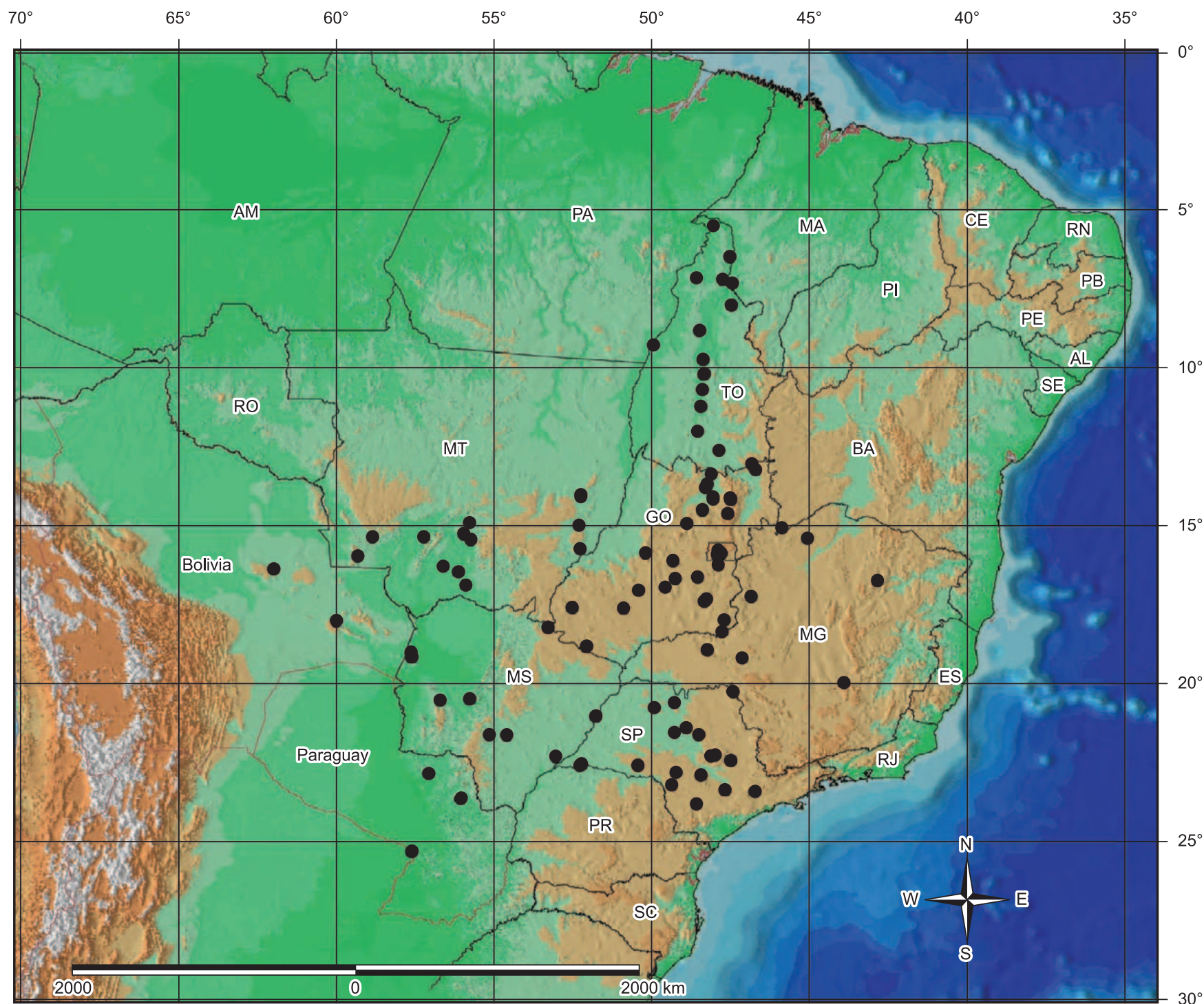

Figure 2. Geographic distribution of Chiasmocleis albopunctata based on museum records, fieldwork and literature. Abbreviations for Brazilian states are: AL, Alagoas; AM, Amazonas; BA, Bahia; CE, Ceará; ES, Espírito Santo; GO, Goiás; MA, Maranhão; MG, Minas Gerais; MS, Mato Grosso do Sul; MT, Mato Grosso; PA, Pará; PB, Paraíba; PE, Pernambuco; PI, Piauí; PR, Paraná; RJ, Rio de Janeiro; RN, Rio Grande do Norte; SC, Santa Catarina; SE, Sergipe; SP, São Paulo; TO, Tocantins. 
seems to be more abundant in areas where large temporary ponds are formed on a regular basis (e.g. every year at the beginning of the raining season), such as soil declines. The species seems to tolerate degrees of habitat disturbance, since chorusing individuals were found in flooded pastures in Amambay Paraguay (McDiarmid \& Foster 1987) and next to unpaved roads in Mato Grosso Brazil. In Tocantins, larger individuals and females with eggs were mostly found at the beginning and during the middle of the rainy season (Pavan 2007).

The huge altitudinal range and high ability to occupy different habitats is unknown for other species of Chiasmocleis, which are generally more restrict and have narrower altitudinal range. At least three other species also show a broad altitudinal range, although considerably narrower than C. albopunctata: $C$. schubarti (sea level to $800 \mathrm{~m}$ a.s.1.) (Ramos \& Gasparini 2004), C. leucosticta (from 15 to $870 \mathrm{~m}$ a.s.l.) (M.C. Forlani, unpublished data) and C. mantiqueira (from 1000 to $1500 \mathrm{~m}$ a.s.l.) (M.C. Forlani, unpublished data).

\section{Acknowledgements}

We thank C.F.B. Haddad (CFBH), G.R. Colli and M. Ayub (CHUNB), A.L. Prudente (MPEG), H. Zaher (MZUSP), M.A. Carvalho and T. Mott (UFMT), R. Heyer and R. W. McDiarmid (USNM) for access to specimens or information from collections under their care. J. Köhler and M. Jansen, kindly provided photos of specimens collected by them. F. Curcio, F. Centeno, J. M. Ghellere, S. Pavan, R. Brandão and C. Nogueira, were pleasant companions in various fieldtrips. PLVP is supported by a fellowships from Coordenação de Aperfeiçoamento de Pessoal de Nível Superior / Fulbright Commission (CAPES/IIE, process number BEX 2806/096), and the Richard Gilder Graduate School at the American Museum of Natural History.

\section{References}

AQUINO, L., COLLI, G., REICHLE, S., SILVANO, D. \& SCOTT, N. 2004. Chiasmocleis albopunctata. In IUCN Red List of Threatened Species (International Union for Conservation of Nature - IUCN). Version 2009.1. IUCN. www.iucnredlist.org (ultimo acesso em 18/10/2009).

BRASILEIRO, C.A., SAWAYA, R.J., KIEFER, M.C. \& MARTINS, M. 2005. Amphibians of an Open Cerrado Fragment In Southeastern Brazil. Biota Neotrop. 5(2): http://www.biotaneotropica.org.br/v5n2/ pt/abstract?article+BN00405022005 (ultimo acesso em 07/12/2010).

CARAMASCHI, U. \& CRUZ, C.A.G. 1997. Redescription of Chiasmocleis albopunctata (Boettger) and description of a new species of Chiasmocleis (Anura: Microhylidae). Herpetologica 53(2):259-268.

CRUZ, C.A.G., CARAMASCHI, U., IZECKSONHN, E. 1997. The genus Chiasmocleis MeÂhely, 1904 (Anura, Microhylidae) in the Atlantic rainforest of Brazil, with description of three new species. Alytes 15:49-71.

DE LA RIVA, I., KÖHLER, J., LÖTTERS, S. \& REICHLE, S. 2000. Ten years of research on Bolivian amphibians: updated checklist, distribution, taxonomic problems, literature and iconography. Rev. Esp. Herpet. 14:19-164.

DE LA RIVA, I., MARQUEZ, R. \& BOSCH, J. 1996. Advertisement calls of four microhylid frogs from
Bolivia (Amphibia, Anura). Am. Midl. Nat. 136:418-422. http://dx.doi. org/10.2307/2426746

FORLANI, M.C. 2010. Variação morfológica do gênero Chiasmocleis Méhely 1904 (Anura, Microhylidae, Gastrophryninae) e suas implicações filogenéticas. Dissertação de Mestrado, Universidade de São Paulo, São Paulo.

FROST, D.R. 2011. Amphibian Species of the World: an Online Reference. Version 5.5. American Museum of Natural History, New York. http:// research.amnh.org/herpetology/amphibia/ (ultimo acesso em 02/02/2011).

GIARETTA, A.A., MENIN, M., FACURE, K.G., KOKUBUM, M.N.C., \& OLIVEIRA FILHO, J.C. 2008. Species richness, relative abundance, and habitat of reproduction of terrestrial frogs in the Triângulo Mineiro region, Cerrado biome, southeastern Brazil. Iheringia, Sér. Zool., Porto Alegre 98:181-188.

GORDO, M. \& CAMPOS, Z. 2003. Listagem de anuros da Estação Ecológica Nhumirim e arredores, Pantanal Sul. Documentos. Embrapa Pantanal, Corumbá, v.58, p.1-21.

McDIARMID, R.W. \& FOSTER, M.S. 1987. Additions to the reptile fauna of Paraguay with notes on a small herpetological collection from Amambay. Stud. Neotrop. Fauna Envir. 22(1):1-9. http://dx.doi. org/10.1080/01650528709360714

OLIVEIRA FILHO, J.C. \& GIARETTA, A.A. 2006. Tadpole and advertisement call of Chiasmocleis albopunctata (Anura,Microhylidae) from Brazil. Zootaxa 1353:63-68.

PAVAN, D. 2007. Assembléias de répteis e anfíbios do Cerrado da bacia do Rio Tocantins e o impacto do aproveitamento hidrelétrico da região na sua conservação. Tese de Doutorado, Universidade de São Paulo, São Paulo.

PELOSO, P.L.V. \& STURARO, M.J. 2008. A new species of narrow-mouthed frog of the genus Chiasmocleis Méhelÿ 1904 (Anura, Microhylidae) from the Amazonian rainforest of Brazil. Zootaxa 1947:30-52.

RAMOS, A.D. \& GASPARINI, J.L. 2004. Anfíbios do Goiapaba-Açu. Gráfica Santo Antônio Vitória, Espírito Santo.

SANTANA, D.J., SANT'ANNA, A.C., SÃO-PEDRO, V.A. \& FEIO, R.N. 2009. The advertisement call of Chiasmocleis bassleri(Anura, Microhylidae) from Southern Amazon, Mato Grosso, Brazil. South Am. J. Herpetol., 4:225-228.

SILVA, F.R., PRADO, V.H.M., VASCONCELOS, T.S., SANTOS, T.G. \& ROSSA-FERES, D.C. 2009. Amphibia, Anura, Microhylidae, Chiasmocleis albopunctata: Filling gap and geographic distribution map. Check List 5(2):314-316.

SCHULZE, A., JANSEN, M. \& KÖHLER, G. 2009. Diversity and ecology of anuran communities in San Sebastián (Chiquitano region, Bolivia). Salamandra 45 (2):75-90.

UETANABARO, M., SOUZA, F.L., FILHO, P.L., BEDA, A.F. \& BRANDÃO, A.B. 2007. Anfíbios e répteis do Parque Nacional da Serra da Bodoquena, Mato Grosso do Sul, Brasil. Biota Neotrop. 7(3): htp://www. scielo.br/scielo.php (?pid=S1676-06032007000300030\&script $=$ sci_ abstract\&tlng=PT (ultimo acesso em 07/12/2010). 
Appendix I. Voucher specimens

BOLIVIA: Santa Cruz: (De La Riva et al. 1996, 2000, 2006); Hacienda San Sebastián (Schultze et al., 2009). BRAZIL: Bahia: Cocos (CHUNB 50330). Distrito Federal: Brasília (UNESP/SJRP 1857); Fazenda Água Limpa, Brasília (Caramaschi \& Cruz 1997); Jardim Botânico de Brasília (CHUNB 43299). Goiás: Alto Paraíso (ZUFG 2579); Aporé (ZUFG 2414); Barro Alto (ZUFG 3561); Catalão (ZUFG 2128); Cidade de Goiás (ZUFG 2766); Goiânia (ZUFG 3194); Goiatins (CHUNB 57060); Guapó (ZUFG 1372); Luziânia, Integração de bacias (CHUNB 38689); Colinas do Sul, LT Serra da Mesa (CHUNB 44707); Três Ranchos, LT Serra da Mesa (CHUNB 44738); Niquelândia (ZUFG 3036); Orizona-Buritizinho (MZUFV 6482); Mineiros, Parque Nacional das Emas (CHUNB 15324); Petrolina de Goiás (MZUSP 126712); Pires do Rio (CHUNB 38690); Pires do Rio (MZUFV 6518); Ponte sobre rio Bezerra, na estrada que liga Arraias a Monte Alegre de Goiás (MNRJ 17859); Rio verde (CHUNB 49437); São Domingos (CHUNB 35565); Serra da Mesa, ponto 3 (MZUSP 72354); Paraúna, Serra das Galés (MNRJ 48582); Silvânia (ZUFG 465); Minaçu, UHE Cana Brava (MZUSP 130610); UHE Serra da Mesa (MZUSP 89408). Maranhão: Carolina (CHUNB 51830-33). Minas Gerais: Belo Horizonte, Lagoa Seca (Caramaschi \& Cruz 1997); Formoso, Parque Nacional Grande Sertão Veredas (CN 403, field number, no collection number); Margem do rio Itacarambuçu, Cristália (MNRJ 17027); Perdizes (Giaretta et al. 2008); Uberlândia (MNRJ 17326; Oliveira-Filho \& Giaretta 2006; Giaretta et al. 2008); Paracatu (MNRJ 37067). Mato Grosso: Água Boa (PVH 2346, field number, no collection number); Alto Taquari (CN 0276, field number, no collection number); Barra do Garças (PHV 2361, field number, no collection number); Carandasinho (Caramaschi \& Cruz 1997); Chapada dos Guimarães (CFBH 14393); Chapada dos Guimarães, Manso (Caramaschi \& Cruz 1997); Jauru (MHO 33, field number; UFMT, no collection number); Pirizal (PIR 092, field number; UFMT, no collection number); Poconé (UFMT 3926-27); Pindaíba (MZUSP 90906); Porto Estrela (MZUSP 133007); Tesouro (MZUSP, no collection number); UHE Manso (MZUSP 98881). Mato Grosso do Sul: Aquidauana, Vale das Bruxas (MNRJ 17858); Aquidauana, (Caramaschi \& Cruz 1997); Bela Vista, Fazenda Barreiro (Caramaschi \& Cruz 1997); Bodoquena (Uetanabaro et al., 2007); Corumbá (IAH 206); Maracajú (Caramaschi \& Cruz 1997); Três Lagoas (CFBH 18477); UHE Sergio Motta (MZUSP 96884); Urucum (Gordo \& Campos 2003). Pará: Tucuruí (MZUSP 82135). São Paulo: Águas de Santa Bárbara, Estação Ecológica de Santa Bárbara (CN 968, field number, no collection number); Assis, Estação Ecológica de Assis (CFBH 19998); Botucatu, Rubião Junior (MNRJ 16624); Brotas (CFBH 9837); Buri (MZUSP 134880); Itirapina, Estação Ecológica de Itirapina (Brasileiro et al. 2005); Iperó (Caramaschi \& Cruz, 1997); Macaubal (DZSJRP 11751); Matão (DZSJRP 11752); Novo Horizonte (DZSJRP 11750); Onda Verde (DZSJRP 11384); Pindorama (DZSJRP 1347-1); Pedregulho (CFBH 13999); São Paulo, Perus (MZUSP 924); Pindorama (DZSJRP 1347); Piraju (MNRJ 50879); Rio Claro (CFBH 5654); Teodoro Sampaio (CFBH 12084); Teodoro Sampaio, Parque Estadual Morro do Diabo (DZSJRP 11456). Tocantins: Aguiarnópolis (CFBH 19906); Araguatins (MPEG 29414); Babaçulândia (MZUSP 126996); Guarai (MZUSP 127128); Ipequeiras (MZUSP 127322); Muricilândia (MNRJ 51444); Palmas (MZUSP 90164); Palmas, Aeroporto Brigadeiro Lysias Rodrigues (CHUNB 25083); Paranã (MZUSP 111685); Peixe (MZUSP 122717); UHE Eduardo Magalhães (MZUSP 137810); Caseara, Parque Estadual do Cantão (CHUNB 45602); Porto Nacional (CHUNB 15322). PARAGUAY: Amambay, Parque Nacional Cerro Corá, (USNM 253141); Asuncion (Caramaschi \& Cruz 1997); Villa Sana (Mehely 1904). 